\footnotetext{
特集 教授定年退職

特集 記 念講 演

順天堂医学 38 (2) P. $183 \sim 191$ (1992)
}

\title{
老年期精神障害の早期診断**
}

\section{Diagnostic procedure of the elderly psychotic patients}

\author{
飯 塚 禮 二* \\ REIJI IIZUKA, M.D.
}

\begin{abstract}
本文はすでに「精神科治療学」5 巻873〜881（1990）に，ほぼ同様の内容が発表されており， 従って原著ではない. 平成三年度 P 5 医学心理学の同じ課題の講義が, 私の最終講義となったの でこてに掲載させていただくこととした。

なお, 平成 4 年 3 月 25 日の講演会当日の講演内容は, 未だ学会で未発表のものであるため本稿 を掲載した。
\end{abstract}

索引用 語: 老年期精神障害, 痴呆, アルッハイマ一型痴呆

Key words : seuile psychoses, dementia, alzheimer type of dementia

\section{はじめに}

世界一となったわか泪の長寿化に伴って, 老人 の福祉と医療についての論議がしばしば行われる ようになった. 高齢の患者が受診・入院し, 更に 手術を受ける機会は急速に増えつつある.

精神科の領域においては, 種々の原因に基づく 老年者の痴呆についての介護, 老年痴呆（以下特 にととわらない場合は Senile dementia of Alzheimer type, すなわち, 従来の初老期痴呆として の Alzheimer 病と老年痴呆 Senile dementia の 両者を含むものとしてての言葉を用いる）につい ての基礎的研究の進歩, 血管性痴呆と老年痴呆の 鑑別, その薬物治療の開発などに関心が集中して おり, 痴呆を軸として老年精神医学が考えられる 傾向にある.たしかに臨床の実際から云えば,

* 順天堂大学医学部精神医学講座名誉教授

Department of psychiatry, Juntendo University School of Medicine, Tokyo, Japan

** 第260回順天堂医学会学術集会 $[M a r .25,1992$ 開催 〔May 20，1992 原稿受領〕
このととは当然かも知れないが反面, 老人がなん らかの精神症状を示す原因は極めて多彩である。 しかも老人の特徽として早期に診断して適切な治 療を行うか否かによって, 予後に及ぼす影響は極 めて大きい. 本日は実際に私共の前に精神症状を 示す老人が受診した場合, どういうことを頭にお いて, どんな順序で診察を進めるかという觀点か ら述べようと考えた。

\section{老年患者の基本的な精神状態 ——精神老化——}

\section{1. 身体の老化性変化とその意味}

年齢と共に全身の臓器に老化性の変化が現われ る. その現象や病理学的変化はよく知られている が, 発生機序や臨床的意義については不明のもの も少なくない. 脳もこの老化性の変化が最も顕著 に出現する器官のひとつである. なかでもアルッ ハイマー神経原線維変化や, 老人斑をはじめ顆粒 空胞変性・小脳プルキンエー細胞のトルペードー （軸索膨化）形成などは古くから知られた代表的 なものである. また血管系の老化性の病変の代表 
である動脈硬化が脳動脈に現われることは多く, その結果, 脳血管痴呆を代表とする様々の神経精 神症状が現われることは周知の通りである.

これらの老化性変化は一定以上の年齢になれば, その程度や分布は別としてほとんどすべての人に 現われると考えてよい. この場合老年痴呆では, その病変の量も分布も明らかに平均域を越えてお り,一方, 健康な精神生活を送った老人の脳にも 同じ種類の変化は, 少量かつ局限された範囲とは 云えほとんど発見出来るのが常である.乙れらの 場合, 老年痴呆では明らかに脳の病変と臨床症状 との間に因果関係を想定できるが, 脳動脈硬化症 を含め軽い老化性病変を脳にみる場合, 乙れと精 神症状との関連性を断定することは極めて難しい． 一方, 最近の P E T などの結果を待つまでもなく, 老人では脳血流量・脳グルコース代謝率が低下し, 血管抵抗が増大していることは古くから知られて いた. 形態学のみならず病態生理学的にも, 老人 の脳のありようは若い頃とは異なっているものと 考えなくてはならないが，てれが可逆的な精神神 経症状とどのような因果関係にあるかは，なお不 明の点も多い。

2. 老人の精神的特徵——精神老化の一般症状—

老人の精神老化の特徵として古くから云われて いるのは, 記憶力ととに最近経験した事柄の記憶 の障害, いわゆるくド忘れ>と称される想起障害 （乙れは特に姓名の想起にいちじるしい，感情の 不安定性と意欲の低下, 無関心, 性格の変化, こと に従来の性格の尖鋭化のためにてれまで長所とし て働いてきた性格傾向が，むしろ短所として印象 ゔけられること（自己中心的・猜疑心が深い・ 無遠慮・愚痴っぽい）などが一般に挙げられて いる. また老人は一般に不安心気状態・不安抑 うつ状態に陷り易い特徵があるとともよく知ら れている.

3. 老人をとりかとむ状況の変化

現在の社会は極めて流動的で変化に富んでいる。 物質的な欲望や便利な生活の可能性を充足するこ とは, 以前にくらべ比較的容易となった．しかし ながら, 精神的な弾力性に乏しく, 従来の経験を
通して学習した結果を大事にすることによって, 生きて行てうとする老人にとっては激しい変化に うまく適応して行くことは, 若い人の予想を越え た困難事であるととが多い. 生産可能性の多寡に よってその人の評価がきまりかねない現在の社会 では, 身体的おとろえも同時に伴っている老人に とっては，その中で以前と同じ自信と自己評価を 持つとと自体が困難になって来つつあるといえよ う.この問題は職場では定年——再就職などの形 でただちに経済面にも影響する。

一方, 家族の中ではこれまで一家の長としての 誇りと自信を持ち, 尊敬されていた立場は摇いで, 経済的実権も次代に移ってゆく．乙のことは家庭 内での老人の安住をどのように確保するかの問題 ともからんで, 次第に身体的衰えを自覚してゆく 老人の気持を, ますます不安にかりたてる可能性 を含む. 配偶者・兄弟をはじめ身近の者を失うこ ともしばしばである.

こうして若い者と一緒に共同社会の活動を荷な いたいと希望する一方で，いたわりと安息を与え られることを期待しながら, 毎日を送るのが一般 的老人の姿といえよう.

\section{老年の患者に相対したら}

\section{1. 受診の目的}

精神科の外来では, 成人患者が単身で受診した か, 付添いと一緒かによってある程度までの疾患 内容の判断さえも出来ることがある.しかし高齢 者の場合は例外を除いてほとんどが，付添または 他科専門医の紹介状と一緒である。 まずこれらを 通して精神科受診の目的, あるいは患者・家族, 他の専門科の医師の精神科医に対する要望や依頼 を明確にすることが必要である. 老人の患者では, 患者自身の敛みや希望の他に，周囲の者が患者か ら受ける苦労や心痛が受診の動機となる場合が多 い. しかも患者と付添者との身分関係などによっ ては, 案外肝腎の点が明らかにされずに，まわり くどい表現や，二次的・三次的な問題点が前面に 出て, 本質の所在が把握しにくい場合も存外に 
多い.とのととは予診をとるにあたって心してお く必要がある.

\section{2. 病歴}

高齢者であるから生活史は長く, 家族歴も遡り にくい場合も多いが, 可及的細かい家族歴と生活 史を得ることは, 老年患者の元来の性格や社会適 応・家族関係等を知る上で重要である.また過去 から現在までの同居家族の構成を知ることは，そ の患者に対して, 家族がどういう環境的条件や精 神的態度で接しているかを明らかにする上で重要 である. 後に述べるように, 老人の精神症状の中 には慢性難治性で, 現在のところでは回復に向け ての治療よりは,むしろ長期間の介護に重点をお かざるを得ないととも多い. この場合, 診断のは じめから，その患者の扔かれている人間関係の客 観的状況と, 表面には現われにくい雾囲気とを知っ ておくことは, 患者の症状や経過の理解の上にも 大切である.また患者の性格や社会内での人間関 係を若い頃に遡って知っておくことは, 後に述べ るように, 精神的な老化の場合に元来の性格の尖 鋭化がまず微妙な人間関係の変化として現われて 来ることが少なくないので, 大きな参考となる． しかしながら，配偶者や同胞がない場合にはなか なか困難であるし，老人をとりかてむ家族間では， その老人に対して主観的な色彩の強い判断が述べ られることが多いので, 出来ればなるべく多くの 関係者から, 繰り返し情報を得るように心掛ける ことが大切である.

\section{3 . 現在症}

本人あるいは付添者から, 受診の目的や, 乙れ までの性格, 生活史, 現在の状況等を知ったなら ば, 現在症の把握にとりかかる。この場合もっと も最初に考えるべきことは (1) 元来の知能程度 と最近の変化 $(2)$ 意識障害の有無の 2 点を出来 る限り正確に把握するととである.乙れは何も老 人に限らず,すべての精神医学的診察の出発点で ある.すなわち精神薄弱と意識障害を除外した所 からはじめて, その他の精神疾患の診断が出発す るのであるが, 最近はての点が比較的見逃されて いる傾向がある. 次いで（3）覚醒度の把握
(4) 身体所見へと進む.

( 1 ）元来の知的水準の把握

老人の元来の知的水準がどの程度であったかを 知るととは二つの点で重要である.すなわち第一 は元来知的水準のあまり高くない老人の場合, 若 い時は体力もあり,またその当時の社会機構が比 較的単純であったてともあって, その人なりに適 応した社会生活が可能であったのが, 体力と精神 能力の老化のために適応力が低下し, 同時に本人 をとりかてむ社会や家庭の状況が変化した場合に, 知的水準が低く人格構造が単純で, もろい程不適 応を起乙し易く, 様々の精神身体症状の出発点と なることが少なくない.ての点については勿論知 能検査も必要であるが, 後に述べる痴呆との鑑別 を考えるためには総合知能指数のみではなく, 各 項目でとの減退率もよく検討して判断するてとが 必要である. 現実には学歴・職歴・趣味や対人関 係を聞くことによって, 元来の知的水準の凡そを 推定することが可能なととが多い.

（2）意識障害

老人は種々の身体的および精神的悪条件のもと で, 意識障害を示す場合が少なくない. 勿論, 意識 障害がある程度以上になればその判断は困難では ない.ここで問題となるのはごく軽い意識障害, 最近の脳神経外科の規準でいえば $I_{1} \sim I_{2}$ 程度の場 合である. 後に詳しく述べるが, 軽い意識障害が 痴朵と誤解されていることがしばしばある.てれ は意識障害の起こりはじめにも, また重い意識障 害からの回復の過程においても起こりうる. その 鑑別はなかなか困難なととも多い. 勿論, この場 合の意識障害および痴呆はいずれも軽いものを指 しており，それぞれの状態像が完成した場合には 鑑別は困難ではない。

( 3 ) Vigilance（覚醒度）の把握

人間の意識状態は常に同一なものではなく, 通 常一定の周期と幅の範囲内で大きく変化しており, その間に状況に応じて様々の変化が絶えず起てっ ている.たとえば, 混雑した通勤電車の中で立っ てもまれているときは覚醒度は比較的高く保たれ るが, うまく座れると低下しはじめることが多い. 
最も周期がはっきりとしでおり，一定性のあるも のの例としては睡眠と覚醒のリズムがある. 覚醒 度が年齢によってどう変わるかの検討は, 脳波と 日内リズムの変化の研究を基礎として発展したが, その知見は比較的最近になって得られたものが多 い. 老齢の患者の精神状態の把握には, 覚醒度の 変化を少なくとも数日以上のリズムの恒常性と, 変化の両面からとらえるように心掛けておくこと が重要である. それは意識障害の初期には覚醒度 の低下を必ず伴うし，また薬物を用いるにあたっ て, その薬物が覚醒度をどう変化させるかを考え るととも重要である.たとえば原則として, 夜間 は覚醒度を下げて睡眠の導入を容易にし, 昼間は 覚醒度を上げて精神活動能力の水準がより高く保 たれるようにすることが望ましい. 薬剤の効果が これに逆に㗢くとなかなか望まれる治療結果は得 難いことになる.

\section{(4) 身体的検査}

老年に伴って身体の多くの藏器に加齢に基づく 変化が起こる. そのうち一部はさまざまの自他覚 的症状を伴い，〈疾患〉として治療の対象となる. これらのうちには生理的な老化現象として考えら れるものも数多く，疾患〉との境界は必ずしも 明瞭ではないことも少なくない. 極端にいえば, ほとんどすべての老人は詳細に検査すれば,いく つかの<疾患〉を持っていることが多い. 眼科・ 耳鼻科・歯科等の疾患の中には, ことに生理的老 化としての変化か揤〈疾患〉としてとりあげられ る場合が少なくない. 従って老人の身体的検索佂 際しては, 必ずといってよい程まで発見される生 理的変化ともいえるく疾患〉と，ただちに治療を 必要とする<病変〉とを区別することが先ず大切 である.

老人の場合, 時にてれらの身体的な障害の訴え 方が, その時々の状況によって, あるいは診断者 に対する患者の感情的な態度によって全く異なっ たり,あるいは, 精神的に加工されて違った形で 述べられる場合があることを心得ておくことが必 要である.乙れは家庭や入院生活における老人の 健康状態, ことに自覚的訴えがその老人の感情や
情緒的反応によっていちじるしく異なって，時に は一体どの程度に判断したらよいのか迷う場合の あるとととも共通している。

\section{老人の心因反応と神経症一一代償とその破綻 —多元的観点の必要性一}

以上述べた所をまとめると，老人の存在は身体 的（これは脳が最も重要かつ中心的ではあるが， 決して脳のみに限らない）制限と, 元来の性格に 深く結びついた老人の心性に由来する条件と, 家 族を含めてひろく現代一般社会の持つ特徽と, い くつもの要因によって規定されているてとがわか る. 老人はこのような複雑にからみあった, 自己 と他者との流動的な関係の中で生きていると考え なくてはならない. この様相は不安定な基礎の上 にあって,なんとか精神・身体両面での平衡を保っ ている状態に他ならず，てれがどうにか可能な限 りは，その老人はく病人〉としての症状や訴えを 示さずに社会生活を続けるととが可能である.す べての老人は何等かの意味で不確実な部分や変化 した部分を持ちながら，与えられた条件の下で生 きている訳である.ての状態はとりもなおすず, 代償に成功して社会内に止まっていると表現できる

この代償状態は,いずれかの点で平衡がくずれ れば容易に破綻におちいる。身体条件が悪化した 場合でも, 環境条件に急激な変化が起こった場合 でもそれは同様に起こりうるし，現われる症状も その原因の如何を問わずその人に固有の傾向があ る. 特に元来の性格に出発する精神的老化のあり ようが重要な鍵を持つ.との点は代償不全から再 代償状態へと回復する可能性を考える場合に特に 重要である.

老人の示す多くの精神症状，乙とに心因反応む るいは神経症の範疇に入るものの経過は, まさし くてれに相当する. 従って, ある一つの状況要匡 や身体要因をとりあげるよりは，その老人をとり かてさ多元的要因の相互布置をまず大づかみに把 握し，その中で最も意義の大きいもの，あるいは 治療的働きかけによって, 変化させ得るものを早 
く見極めることが早期診断にとって重要である. なぜならば, 経過と症状の相違はあるものの, ほ とんどの場合, 老人の可逆性精神症状はその老人 つ人間生活における代償能とその破綻, そしてそ れからの再構築の経過と考えられるからである.

\section{痴呆}

老人の示す精神症状の中には, 痴呆と意識障害 亿基づく部分が重要な役割を荷なっていることが 叒めて多い.乙れらの症状のゆえに, 様々の行動 つ異常を伴うことは当然である. 従って鑑別診断 つためには, 患者の示す全体の病像の中で, 㾰呆 と意識障害の果たしている役割の大きさを見分け ることが重要である. 通常, 次のような手順でこ つ問題を整理するのが便利である.

\section{1. 精薄と痴呆}

痴呆は元来, 一度は正常域にまで発達した知能 が脳の器質性障害のために持続的に低下したもの であり, 精薄は何等かの原因で，もともと知能発 達が障害されたまま恒常的に経過するものである. 促って, 生活史と病歴を正確に知ることが出来れ ば，その区別はそれほど困難ではない. 特に疾呆 の初期には精薄には見られない, 往年の知能水準 の高さの残りが, 面接の際に所々で表現されるこ とに注意する必要がある.

この理念的にはわかりきったととが臨床の実際 では案外見逃がされている.たとえば, Down 症 候群では40歳位で脳に Alzheimer 型疾呆と同様 の病変が見られることは周知であるが, 乙の場合, 通常の Alzheimer 型疾呆が示すような高度の痴 呆には陥らず, 元来の精薄の原型が保存されてい る場合が多い。しかしながら, 最近は専ら脳の病 変の相似性が重要視され, 臨床症状の相違はあま り注目されていない.てういう単純なことが, Down 症候群と Alzheimer 型痴呆の近縁性を不 当に強調して誤解を生むもとともなる.

2 . 意識障害と痴呆

意識障害がある程度以上に重くなれば，その存 在を判断することは容易である.しかし極めて軽
度の場合には，その存否を見極めることはなかな か困難で, 前述したように軽い意識障害を痴呆と 誤診することは決して稀ではない. Wieck のいう 通過症候群とは, まさしくこの点を問題とした概 念である.

\section{3 . 痴呆の原因と鑑別診断}

痴呆の診断基準については最近, DSM III-R・IC D 9 (ICD10原案) などをはじめいくつかのものが 公表され実用化されている.それぞれいくらかの 相違点はあるが, 記憶障害を中心に据え, これに 種々の大脳高次機能障害, すなわち判断力・計算 力障害, 失語・失認・失行等, および性格変化な ぞを加味し, しかもその程度が患者の日常の社会 生活を妨げる程度にまで達していること, またそ の症状の原因として脳器質性疾患が証明, あるい は強い蓋然性をもって疑われること等が挙げられ ている. 臨床の実際では記憶障害, あるいはそれ に基づく行動異常や, 人格変化などを家族をはじ めとする周囲の人々に気付かれて受診に至る場合 が圧倒的に多い. 患者自身がく記憶障害〉（物忘 れの訴）で受診する場合は, 痴呆ではなく, 神経 症圈の心気症状を考えた方がよい.

ところで従来疾呆は脳器質性疾患に基づく症状 であり,一度起乙ると回復不可能な非可逆性症状 であるとされていた。しかし最近は, 治療の対象 となる可逆的な場合でも, 前述の条件を満たす症 状であれば痴呆と呼ぶようになった。すなわち treatable dementia と呼ばれるものである. 従っ て痴呆と診断される症状を診た場合には,まずもっ てての種のいわゆる “原因力脳以外にある”痴呆 を, 鑑別の対象とすることが必要である. 内分泌 系ないしは代謝障害性の疾患が主なものであ り, 臨床症状と検査所見とに基づいて, これら の疾患に想いをいたせば鑑別はさほど困難では ない。

次の段階は脸原発の痴呆（外因性）の鑑別であ る. 慢性アルコール中毒・慢性薬物中毒・頭部外 傷・てんかん等については病歴を正確に得ること, 脳波所見・画像診断等から診断はそれ程困難では ない. C-J 病・進行麻痺・AIDS はいずれも感染 
症の範疇に属する疾患であるが，わが国では現在 のと乙ろ数は多くない. 進行麻㿁・AIDS につい ては血清学的診断が決定的な意義を持ち, C-J に ついて脳波所見が参考となることは周知の通り である.最近はさらにるトコンドリア脳筋症のな かに, Alzheimer 型痴呆を思わせる患者のあるこ とが知られてきた。この場合は血中ピルビン酸値 の測定や筋生検等により診断が可能である.これ らの疾患が, 痴朵症状を示し得ることを基礎的知 識として知っていることは重要であり, 次に患者 を前にして「知らざるにあらず思い至らざるな り」の失敗をしないてとである.

\section{4. 原発性神経変性疾患侸よる痴呆}

Alzheimer 型痴呆・Pick 病がその主要なもの である. その他の神経変性疾患でも痴呆を伴う場 合は少なくないが，そのほとんどは精神症状に基 づいてではなく, 神経学的症状に重点をおいて診 断が下される. その代表的な例は Huntington 舞 踏病である. 最近 Parkinson 病と痴呆について も多くの研究があるが, 少なくとも早期診断に重 点をおいて考える限り, Parkinson 病では明瞭な 疾呆力症状の前景に立つ場合はないと考えてよい. 若し Parkinsonism と痴呆とが早期から明瞭に 認められたならば, 何らかの Parkinsonism を伴 う痴呆性疾患か, Alzheimer 型痴呆と Parkinson 病の合併を考えるのが一般的といえよう。

5. Alzheimer 型痴呆 (SDAT) と脳血管性痴㭧

\section{1 ）脳血管性痴呆}

脳血管性痴杂はそのほとんどが脳動脈硬化のた めに, 脳の循環障害が起こった結果現われる臨床 症状であり,ごく一部に, その他の閉塞性動脈炎 やアミロイドアンギオパチーなどの特殊な動脈疾 患が加わるにすぎない. 従って一般的には, 脳血 管性痴呆という場合には, 脳のみならず全身を含 めての動脈硬化の既往症, および現在症の把握か らはじめなければならない.すなわち血圧・脂質 代謝異常の有無, 糖尿病・腎機能・心機能・眼底 血管像などにまず注意を払うべきである。もっと も動脈硬化は全身の動脈に極めて不均一に起こる ものであるので, 他の藏器に動脈硬化性所見の認
められないことは, 決して脳動脈硬化を否定する 材料とはならない.

脳血管性痴呆については, 従来, もっぱら多発 梗塞性痴呆（Multiinfarct Dementia ; MID）が 代表として考えられていた.すなわち脳動脈硬化 のために脳に多発性の小梗塞巣が, 主として大脳 基底核を中心に大脳皮質・白質に出来るためとさ れる痴呆である.

その臨床特徵は(1)階段的に悪化すること,すな わち症状が急に起こり，その後安定化したと思っ ていると再び悪化する場合が多い. 初期には疾呆 といっても，ある精神機能は比較的よく保たれて おり,いわゆるくまだら痴呆>の特徵を示す. (2) 種々の局所神経症状，たとえば深部腱反射䒕進， あるいはその左右差, Babinski 反射その他の病的 反射の出現, 歩行障害殊に麻痺, 嚥下障害などが 精神症状の出現に伴って現われることが多い. (3) 上記精神身体症状の出現とともに, 意識障害を伴 うことが多いなどに要約し得る.

脳血管痴呆と Alzheimer 型疾呆の鑑別に有用 なものとして, 以前から Hatchinski の脳虚血評価 点数表とか, 松下の天科法とよばれる一種の rating scale が広く用いられている.これらは，いず れも MID を代表的な脳血管性痴呆と考えて考案 されており，その限りにおいては有用性が認めら れる.

一方で最近, 大脳白質にひろくびまん性の血管 性病変を持つ痴呆例の存在が問題となっている. これは大脳白質ことに前頭葉に, CT 上いわゆる Periventricular luciency (PVL) と呼ばれる低吸 収域が認められ，比較的軽いがびまん性に広がる 髄鞘崩壞を示し, 白質の細小動静脈の線維化や小 動脈の硬化像か認められるものである.乙れらの 症例では勿論, 大脳基底核部を中心に小梗塞, あ るいはラクネを伴う場合も多く, MID とは異る独 立した疾患とはいい難い.ただこの種の白質の病 変が, 高度であると Alzheimer 病の初期に類似し た臨床像を示す場合があり得ることに十分留意す る必要がある.臨床上は CT あるいは MRI（T 強 調画像では high density) での PVL に留意する 
以外に特に方法はないのであるが，血管性痴朵の 中にこのような, 臨床的には Alzheimer 型痴呆 によく似た経過をとるものがあることを知ってお く必要がある.

一方, 同じ白質病変を中心とするものに, 古く から云われている Binswanger 病がある。乙れは むしろ後頭葉白質に病変が強く, 髄鞘崩壊も高度 で時に囊胞を形成し, 臨床的には高度の疾呆に陥 るものである.ただしての病気は, 昔から有名で ある割に実際には稀なものと考えられ, 先に述べ た白質障害型との区別も明瞭ではない. また大脳 白質に多数の小梗塞巣がありながら,てれが疲痕 化してCT 上は低吸収像を示さないために, 臨床 上 MID の診断をおきにくい場合もある.

血管性痴呆の診断は, 上に述べた臨床上の特徵 と CT, あるいは MRI などの画像診断から最近 はかなりの確率度で可能となったが, やはり最終 的には剖検の所見を待たなければならない。

2 ) Alzheimer 型痴呆

Alzheimer 型痴呆は稀に見られる家族性発症を 別にすると, 主として散発性に発現し, 女性にや や多い. 老年期（65歳以上）の痴呆患者のうち, わが国では約 $30 \%$ を占めるか欧米ではその頻度 はもっと高い。

発病は徐々で, 初期には精神症状のみが現われ 神経症状は認められないのが常である.臨床的に は前に説明した痴呆の諸症状が認められるが, 殊 に記憶障害——通常はく物忘れ>が異常に高度で ある—が家族から訴えられる場合が多い. 初期 には患者自身も“物忘れがひどくて”と述べるこ ともあるが, あまりそれに悩んでいる様子はない. この点は抑うつ状態や神経症の老人が, 真剣かつ 執拗に〈物忘れ〉を主訴として訴えるのとは異な る. Alzheimer 型痴呆の場合は, 自己の記憶障害 のために起てった周囲への迷惑などはすでに忘れ てしまっている場合が多く, 家族の深刻な訴え方 と奇妙なコントラストを示すととがしばしばであ る. 初期の記憶障害は短期記憶ないし比較的最近 経験したことの忘却で, いわゆる記銘力障害の形 を示す. 従って当然, 見当識も不確実となる. 次第
に長期記憶も障害され，てれらは進行性の経過を とる.血管性痴呆の際にしばしば見られる,『記憶 障害』の程度が日によって消長を示すことはまず 見られない. これはすでに述べた通り, 特に急性 期からの回復後に『血管性疾呆』の患者が示す 『記憶障害』には, 多かれ少なかれ自然経過として の意識障害が加わっているからである．従って Alzheimer 型痴呆患者の初診時には, 病歴を出来 る限り詳細に聞いて, 少なくとも精神身体症状の なかに, 血管性をはじめ何らかの意識障害のエピ ソードを考えさせる症状は認められなかったこと を確かめ得れば有用な判断資料となる.

引き続いて判断力障害・抽象思考の障害, その 他, 高次脳機能の障害が加わって次第に人格水準 が低下する.乙れらは約 $1 \sim 2$ 年間に経過する場 合が多く通常第 I 期と呼び，なお不十分ながら独 力で身辺の整理を行うことは可能である. 続いて 50〜60歳台位までに発病した狭義の Alzheimer 病では, 失語・失認・失行等の巣症状が明らかに 認められる場合が多いが, 高齢発症の時にはそれ 程に明らかではない. 痴呆がある程度進行した頃, 付随的な症状として, 抑うつ状態 - 不眠 - 俳徊 ・ 妄想幻覚・易刺激性・感情の変わり易さ,などさ まざまの精神症状や，それと関連する行動の異常 を認める場合が多い. これらは介護者の立場から は, 痴呆それ自体よりも苦労する症状である. 幸 いなととにこれらの精神症状は, 適当な薬物治療 と治療環境の配慮とによって比較的軽快し易い場 合が多いので, なるべく早く必要な治療を行うべ きである.

上述の不眠・俳徊に伴い, あるいは引き続いて, 殊に夜間を中心にせん妄状態の出現することがあ る. 多くは精神的あるいは身体的なきっかけに引 き続いて, 軽い精神運動興奮と幻覚妄想を伴った 意識障害の形で出現する. 初期からの経過を知る ことが出来れば, Alzheimer 型疾呆の経過中に現 われたせん妄状態と判断出来るが, 初診であると 血管性痴呆の初期症状としての脳循環障害の結果 の症状かと迷わされ易い. また Alzheimer 型痴 呆の経過中に脳循環障害が起こり, 混合型疾呆 
(Alzheimer 型痴杂の脳病変と, 血管障害による 脳病変が共に存在して, 臨床上の疾呆症状が, 主 としてそのいずれに基づくかを判断し難いもの. 全疾呆患者の約 $10 \%$ 位にみられる) へと進行して ゆく場合もあり得ることを忘れてはならない。

発病後 $2 \sim 3$ 年経過して, 上述のような症状が 見られるようになると常時介護が必要となり, 時 に全身痤攣発作やミオクロニーなどが現われる. CT 像や MRI では, 大脳皮質と脳室系両方の左 右対称的な拡大, すなわち脳萎縮像が明瞭に認め られる. 初老期発症の狭義の Alzheimer 病では, この時期に錐体路症状, 錐体外路症状をはじめ神 経症状がほとんどの症例に出現するが, 高齢発症 では痴呆を中心とした精神症状が中心の場合が多 い.

次いで失禁・発語減少から無言・意志発動性が 減じて食事にも介助が必要となり, 最終的には認 識能の喪失に陥り, 失外套症候群の状態となる。 この状態を第吕期と呼ぶ. 最近はケアが良好となっ たせいもあり, 第吕期は約10年近く続く.

以上のような臨床経過から, Alzheimer 型痴呆 の臨床診断はほほ可能であるが, 確診は剖検によ らなくてはならない。

6 . 痴朵の評価法とその早期診断上の意義

痴呆の疑いのある患者を診察した際に，その有 無および程度を評価したいと考えることはしばし ばある.この目的のために, 最近は種々のテスト がひろく用いられるようになった。 わが国では長 谷川式簡易知能評価スケール・国立精研式痴呆ス クリーニングテスト・MMS (Minimental State Examination, 邦訳版あり)・GBS などいくつか のものが用いられている. 重要なととは，（1）乙 れらのテストにはそれぞれの作成にあたって目的 とする所があり,一様ではないとと（2）乙れら のテストの得点を優先して痴呆の診断を行うので はなく, 診察の結果をテストである程度確認する ものであるという思考の順序をあやまらないこと （3）意識障害があると思われたならば行わない ことである.

\section{老人の妄想と幻覚}

一内因性病像—

老人が妄想や幻覚を示すことは決して少なくな い.てれらの症状を主訴として受診した場合には, 前述の通り痴呆・意識障害（せん妄状態）, 時には 老人性難聴等についてまず考慮することが重要で ある. 殊にてれまで全く健康な社会生活を行い, 幻覚や妄想を示したことのなかった老人が急にこ れらの症状を示した場合には，まず第一に脳およ び全身各臓器に何らかの疾患が発病し，その結果 症候精神病としての幻覚妄想が現われたのではあ るまいかと考えて, 必要な診察および検査をただ ちに行うべきである.一般的常識としては，ての ような場合意識障害が前景に出てくるが，時には 妄想幻覚が主要症状となる場合もあり得る.

痴呆老人が経過中に妄想幻覚を示すことが少な くないてとはよく知られている.ての場合は, 患 者の示す痴呆の程度に応じてその内容もまとまり がなく単純で, 通常はひとつのテーマが長続きせ ず転導性に富んでいるものが多い.ただ軽い痴呆 の場合は, 老人が確信をもって述べるとかなりの 真実性を帯び, 時には家族までそれに巻き込まれ てしまい判断が難しくなる場合もある. また前述 したように, 痴朵の有無にかかわらず老人の場合, せん妄状態に陥り易く, この場合には当然幻覚や 妄想が活発に見られることが少なくない。

以上はいずれも，てれまで幻覚や妄想を示さな かった老人が急速に症状を示した場合の問題であ る.もし若い頃から妄想幻覚が続き, 精神分裂病 の診断を受けたことのある老人が，最近これらの 異常体験が再発，あるいは活発化した場合には， 長期経過の中で老人となった精神分裂病患者とし て考えてよい.むしろ老人の精神分裂病患者は滅 多に老年痴呆には陥らないが，脳血管障害による 諸症状（必ずしも痴呆とは限らない）を併発する ことがままあり，その場合意識障害を伴う妄想幻 覚が現われることがある.乙れを従来の精神分裂 病による妄想幻覚と鑑別することは治療上の観点 からも重要である。 
老年期に入って，てれまで述べた他の疾患を除 外して最後に残るものに, 老年期の原発性妄想状 態あるいは遅発分裂病と呼ばれる一群がある. 学 問的には重要な意味があり，またこの病気の存在 を知っておくことは大切であるが, 頻度の低い疾 患であるのでここでは詳しく述べない.いずれに しても, 鑑別診断のおしまい残されるものであ る.

$$
\text { まと め }
$$

老年期の精神障害の早期診断を考えるにあたつ て, 日頃の臨床で, 著者自身が行っている診断の 順序と考え方の要点について述べた. 毎日の外来 では,ほぼこの程度のととが頭の中で考えられて
いれば，そう大きな間違いは起こさないで診断の 方向性を決められるのではないかという程度の内 容である. 勿論, 比較的容易に難度の高い診断の 出来ることもあれば, いくら苦労してもどうして も判断の出来にくい場合もある. 最後に述べてお きたいことは, 老年精神障害の診断のために是非 必要なととは, 狭義の精神症状を示さない, しか し老人特有の心性が如何にして発現し, どう進展 してゆくかを長く経過を追って観察理解すること で, これがすべての精神症状理解のための基礎知 識となり, 出発点となるものと思う. そう思って 考えれば, そういうく健康な>老人はわれわれの まわりに大勢いるし，やがては自分自身を顧みる ことで事が足りる時がくることになる.

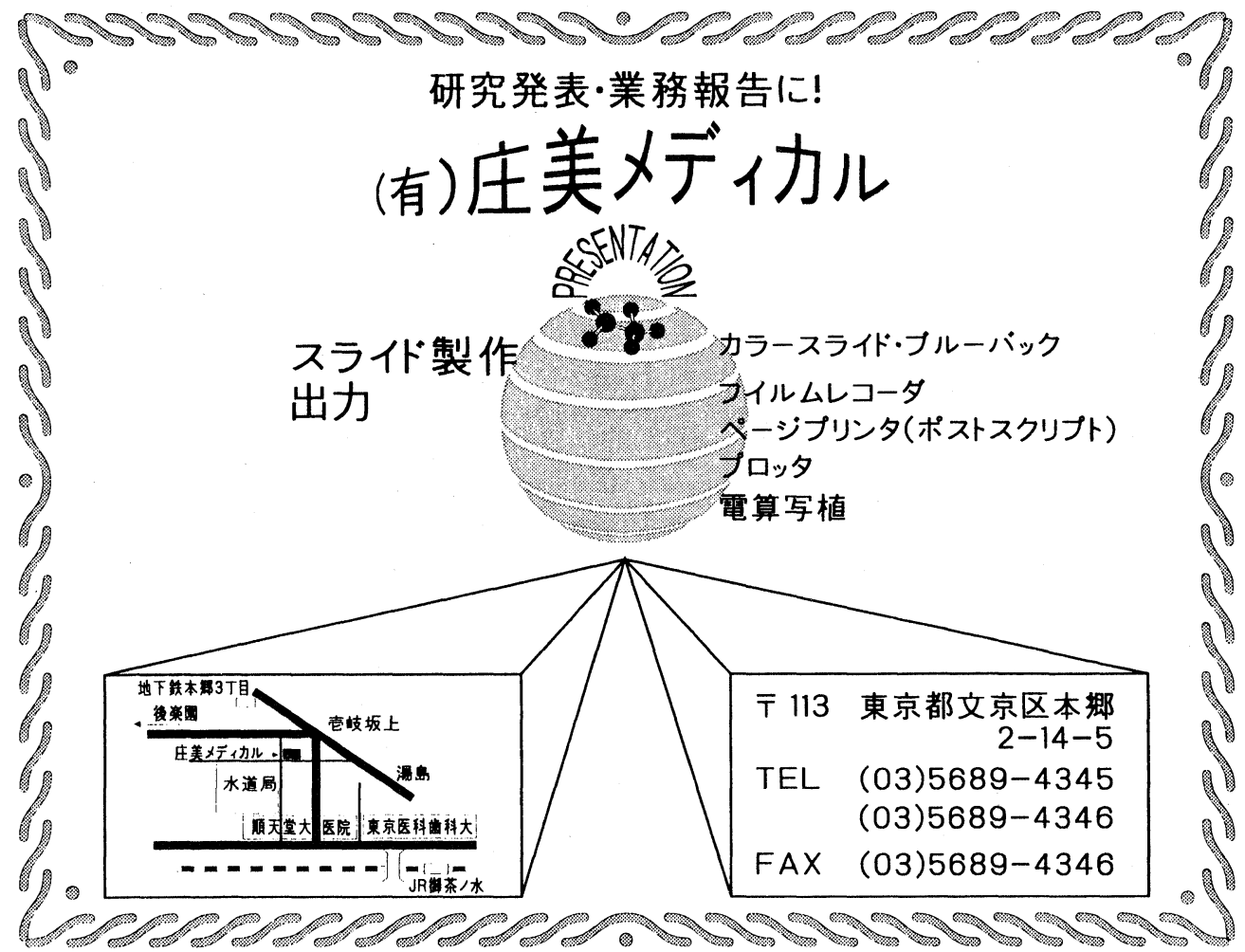

